\title{
Hubungan BBLR dan KPD dengan Asfiksia Neonatorum
}

\author{
Eka Frelestanty ${ }^{1}$, Yunida Haryanti ${ }^{2}$ \\ Stikes Kapuas Raya Sintang ${ }^{1,2}$
}

\section{A B S T R A K}

Informasi Artikel :

Diterima :24 November 2021

Direvisi : 03 Desember 2021

Disetujui : 20 Desember 2021

Diterbitkan : 30 Desember 2021

*Korespondensi Penulis :

Eka.frelestanty@yahoo.com
World Health Organization(WHO), di seluruh dunia terdapat kematian khususnya bayi neonatus sekitar 10.000.000. AKB di kawasan Asia Tenggara merupakan kedua paling tertinggi, yaitu sebesar 142 per 1.000 di Myanmar 48 per 100, Laos dan Timur Leste 46 per 1000,Kamboja 36 per 1.000. Setiap tahunnya kira-kira $3 \%$ (3,6juta) dari 120 juta hampir 1 juta bayi meninggal karena asfiksia. Tujuan dari penelitian ini adalah untuk mengetahui hubungan BBLR dan ketuban pecah dini pada ibu bersalin dengan kejadian asfiksia pada bayi baru lahir. Penelitian ini menggunakan metode deskriptif kuantitatif dengan pendekatan retrospektif, pengambilan data menggunakan data sekunder, tempat penelitian di rumah sakit umum daerah ade Muhammad djoen kabupaten sintang tahun 2021, penelitian ini dilakukan pada bulan April 2021. Jumlah responden sebanyak 277 orang, alat pengumpulan data adalah lembar checklist, analisis data menggunakan analisis univariat dan bivariate. Hasil penelitian yang telah dilakukan tidak ada hubungan antara BBLR dengan Asfiksia pada bayi baru lahirberdasarkan pengujian Chi Square hasilnya p-value 0,17>0,05. Dan ada hubungan yang signifikan ketuban pecah dini pada ibu bersalin dengan kejadian asfiksia pada bayi baru lahir di rumah sakit umum daerah ade Muhammad Djoen kabupaten sintang tahun 2021, berdasarkan pengujian Chi Square hasilnya p-value 0,039<0,05. diharapkan menjadi bahan informasi atau masukan dan acuan perbandingan dalam meningkatkan pendidikan kesehatan terutama pada ibu hamil dan ibu bersalin, melakukan pendekatan atau dukungan psikologis dan dapat lebih meningkatkan pengawasan terhadap kejadian ketuban pecah dini dengan asfiksia pada bayi baru lahir..

\section{Kata Kunci : BBLR, KPD, Asfiksia BBL}

\section{ABSTRACT}

According to the World Health Organization (WHO), around the world there are 10,000,000 deaths, especially neonates. IMR in Southeast Asia is the second highest, at 142 per 1,000 in Myanmar 48 per 100, Laos and East Leste 46 per 1000, Cambodia 36 per 1,000. Every year, approximately 3\% (3.6 million) of the 120 million and nearly 1 million babies die from asphyxia. The purpose of this study was to determine the relationship between low birth weight and premature rupture of membranes in maternity with the incidence of asphyxia in newborns. This study uses a quantitative descriptive method with a retrospective approach, data collection 
uses secondary data, the place of research is the ade Muhammad djoen regional hospital, Sintang district in 2021, this research was conducted in April 2021. The number of respondents was 277 people, the data collection tool was a sheet checklist, data analysis using univariate and bivariate analysis. The results of the research that has been carried out there is no relationship between $L B W$ and asphyxia in newborns based on Chi Square testing the results are $p$-value $0.17>0.05$. And there is a significant relationship between premature rupture of membranes in maternity with the incidence of asphyxia in newborns at the ade Muhammad Djoen regional general hospital, Sintang district in 2021, based on Chi Square testing the results are p-value $0.039<0.05$. expected to be information or input and reference for comparison in improving health education, especially for pregnant women and mothers giving birth, taking psychological approaches or support and can further improve supervision of the incidence of premature rupture of membranes with asphyxia in newborns.

Keywords : low birth weight baby, premature rupture of membranes BBL Asphyxi

\section{PENDAHULUAN}

Bayi dengan berat badan lahir rendah (BBLR) memiliki banyak risiko mengalami permasalahan pada sistem tubuh, karena kondisi tubuh yang tidak stabil. Kematian perinatal pada bayi BBLR adalah 8 kali lebih besar dari bayi normal. Prognosis bayi dengan BBLR akan lebih buruk bila berat badan semakin rendah. Kematian sering disebabkan karena komplikasi neonatal seperti asfiksia, aspirasi, penumonia, perdarahan intra kranial, hipoglikemia. Apabila bayi mampu bertahan hidup dapat terjadi kerusakan saraf, gangguan bicara dan tingkat kecerdasan yang rendah. Prognosis ini juga tergantung dari keadaan sosial ekonomi, pendidikan orang tua, perawatan selama kehamilan, persalinan dan postnatal, pengaturan suhu lingkungan, resusitasi, makanan, pencegahan infeksi dan lain-lain (Proverawati \& Ismawati, 2010)

Menurut WHO diperkirakan sekitar 900.000 kematian bayi baru lahir setiap tahun diakibatkan oleh asfiksia neonatorum. Laporan dari Organisasi Kesehatan Dunia WHO menyebutkan bahwa sejak tahun 2000-
2003 asfiksia menempati urutan ke-6, yaitu sebanyak $8 \%$ sebagai penyebab kematian neonatal diseluruh dunia setelah pneumonia, malaria, sepsis neonatorum, dan kelahiran prematur (Zainuddin, 2012).

Ketuban pecah dini akan mengakibatkan terjadinya oligohidramnion,ini akan mempengaruhi janin karena sedikitnya volume air ketuban akan menyebabkan tali pusat tertekan bagian tubuh janin. Akibatnya aliran darah dari ibu ke janin berkurang sehingga bayi mengalami hipoksia atau gangguan pertukaran $\mathrm{O} 2$ hingga fetal distres dan berlanjut menjadi bayi asfiksia pada bayi baru lahir (Kasim ,2010).

Hasil penelitian yang di lakukan oleh Gilang (2012) angka kejadian asfiksia yang di sebabkan oleh penyakit ibu di antaranya pre eklampsi dan eklampsi sebesar (24\%), anemia $(10 \%)$. Sedangkan pada faktor pada persalinan meliputi ketuban pecah dini ,partus lama /macet sebesar (2,9 $6 \%)$.Berdasarkan data tersebut mengenai ketuban pecah dini dengan kejadian asfiksia di dukung penelitian yang di lakukan 
Mulastin (2014) bahwa terdapat hubungan yang signifikan antara Ketuban Pecah Dini dengan Kejadian Asfiksia Pada Bayi Baru Lahir .

Angka Kematian Bayi (AKB) di Indonesia terus menurun setiap tahun. Namun, jalan memerangi AKB masih panjang. Hasil Survei Demografi dan Kesehatan Indonesia (SDKI) menunjukkan dari tahun ke tahun AKB mengalami penurunan signifikan. Dari 68 kematian per 1.000 kelahiran hidup pada 1991, hingga 24 kematian per 1.000 kelahiran hidup pada tahun 2017. AKB sebagian besar disebabkan oleh asfiksia (20-60\%), infeksi (25-30\%), bayi dengan berat lahir rendah (2530\%), dan ikterus (30-40\%) (SDKI, 2017).

Angka kematian bayi di Kalimantan Barat masih sangat memprihatinkan. Salah satu indikator derajat kesehtaan masyarakat Proporsi terbesar dari angka kemaian bayi terjadi pada masa neonatal. Angka Kematian Bayi (AKB) diKalimantan Barat sebanyak 558 kaus per 100.000 kelahiran hidup kabupaten sintang menempati peringkat pertama dengan 95 kasus. Kematian bayi terbanyak disebabkan oleh asfiksia 35,9\%, BBLR 35,5\%, prematur 34,49\%, sepsis $12,1 \%$, hipotermi $6,35 \%$, ikterus $5,6 \%$, postterm 2,8\% dan kelaina kongenital 1,4\%, (Profil Kaimantan Barat, 2017).

Asfiksia adalah keadaan dimana bayi yang baru dilahirkan tidak segera bernafas secara spontan dan teratur setelah dilahirkan. Hal ini disebabkan oleh hipoksia janin dalam rahim yang berhubungan dengan faktorfaktor yang timbul dalam kehamilan, persalinan dan setelah kelahiran. Menurut Towell (1996 dikutip dari Ilyas, Mulyati \& Nurlina 2012).

Hasil studi pendahuluan di RSUD Ade M. Djoen Kabupaten Sintang pada tanggal 912 April 2021 dengan mempelajari data rekam medis menunjukkan jumlah persalinan selama tahun 2019 adalah 1.300 bayi. Jumlah bayi yang lahir dengan asfiksia adalah 36 bayi. sedangkan bayi dengan BBLR sejumlah 111 dan bayi yang mengalami BBLR dan asfiksia sejumlah 20 bayi. Data rekam medis menunjukkan jumlah persalinan selama tahun 2020 adalah 1.254 bayi. Jumlah bayi yang lahir dengan asfiksia adalah 56 bayi. sedangkan bayi dengan BBLR sejumlah 177 dan bayi yang mengalami BBLR dan asfiksia sejumlah 24 bayi.Begitu pula kejadian ketuban pecah dini (KPD), pada tahun 2018 kejadian KPD sebanyak 119 kasus, dan pada tahun 2019 mengalami peningkatan kejadian KPD sebanyak 48 kasus, pada tahun 2020 sebanyak 60 kasus .

Berdasarkan latar belakang diatas, menunjukan bahwa angka kejadian bayi BBLR dan KPD masih cukup tinggi dan dapat meningkatkan resiko terjadinya asfiksia. Kejadian BBLR, KPD dan asfiksia dapat dicegah sedini mungkin, maka penulis tertarik untuk melakukan penelitian tentang "hubungan BBLR dan KPD dengan asfiksia neonatorum di Rumah Sakit Umum Daerah Ade Mohammad Djoen Sintang Tahun 2021

\section{METODE PENELITIAN}

Ditinjau dari tujuan penelitian, penelitian ini menggunakan penelitian deskriptif kuantitatif dengan pendekatan retropektif, yaitu penelitian yang dilakukan dengan tujuan untuk membuat gambaran atau deskripsi keadaan secara obyektif dengan data yang di paparkan dalam bentuk angka-angka (Notoatmodjo, 2010). Sedangkan retrospektif adalah pendekatan dengan melihat kejadian masa lampau untuk mengetahui faktor resiko yang dialami (Suryono, 2010).

Pada penelitian ini untuk mengetahui hubungan BBLR dan KPD dengan asfiksia neonatorum di Rumah Sakit Umum Daerah Ade Muhammad Djoen Kabupaten Sintang tahun 2021 
Jurnal Kebidanan : Jurnal Medical Science Ilmu Kesehatan Akademi Kebidanan Budi Mulia Palembang Volume.11 No.2, Desember 2021

Available online https://journal.budimulia.ac.id/

\section{HASIL PENELITIAN}

1. Hubungan BBLR Dengan Asfiksia Neonatorum Di Rumah Sakit Umum Daerah Ade Muhammad Djoen Kabupaten Sintang Tahun 2021

Hasil dari analisis data tentang hubungan BBLR dengan asfiksia neonatorum di Rumah Sakit Umum Daerah Ade Muhammad Djoen Kabupaten Sintang tahun 2021 diperoleh melalui lembar checklist pada 277 responden diketahui sebagai berikut :

Tabel 1 Hubungan BBLR dengan asfiksia neonatorumdi Rumah Sakit Umum Daerah AdeMuhammad Djoen Kabupaten Sintang tahun 2021

\begin{tabular}{|c|c|c|c|c|c|c|c|}
\hline \multirow{3}{*}{ BBLR } & \multicolumn{4}{|c|}{ Asfiksia } & \multirow{2}{*}{\multicolumn{2}{|c|}{ Jumlah }} & \multirow{2}{*}{$\begin{array}{c}\text { P } \\
\text { Value } \\
\text { OR }(95 \% \text { CI })\end{array}$} \\
\hline & \multicolumn{2}{|c|}{$\mathrm{Ya}$} & \multicolumn{2}{|c|}{ Tidak } & & & \\
\hline & $\sum$ & $\%$ & $\sum$ & $\%$ & $\sum$ & $\%$ & \multirow{3}{*}{0,17} \\
\hline Ya $\mathrm{BB}<2500$ & 66 & $23,8 \%$ & 104 & $37,5 \%$ & 170 & 100 & \\
\hline Tidak BB $>\mathbf{2 5 0 0}$ & 56 & $20,2 \%$ & 51 & $18,5 \%$ & 107 & 100 & \\
\hline Total & 122 & 44,0 & 155 & 56 & 277 & 100 & \\
\hline
\end{tabular}

Berdasarkan tabel 1 diketahui bahwa bayi yang lahir dengan berat badan kurang dari 2500 gr sebagian mengalami asfiksia neonatorum yaitu sebesar 20,2\%. Sedangkan bayi yang lahir dengan berat badan lebih dari 2500 yang mengalami asfiksia neonatorum yaitu 23,8\%. Hasil pengujian menggunakanChi square memberikan hasil pvalue $=0,17>0,05$. Ha ditolak dan Ho diterima yang artinya tidak ada hubungan antara BBLR dengan asfiksia neonatorum.

2. Hubungan KPD dengan Asfiksia neonatorum di Rumah Sakit Umum Daerah Ade Muhammad Djoen Kabupaten Sintang Tahun 2021

Hasil dari analisis data tentang hubungan KPD dengan asfiksia neonatorum di Rumah Sakit Umum Daerah Ade Muhammad Djoen Kabupaten Sintang tahun 2021 diperoleh melalui lembar checklist pada 277 responden diketahui sebagai berikut :

Tabel 2 Hubungan KPD dengan asfiksia neonatorumdi Rumah Sakit Umum Daerah AdeMuhammad Djoen Kabupaten Sintang tahun 2021

\begin{tabular}{|c|c|c|c|c|c|c|c|}
\hline \multirow{3}{*}{ KPD } & \multicolumn{4}{|c|}{ Asfiksia } & \multicolumn{2}{|c|}{ Jumlah } & \multirow{2}{*}{$\begin{array}{c}\text { P } \\
\text { Value } \\
\text { OR }(95 \% \mathrm{CI}) \\
\end{array}$} \\
\hline & \multicolumn{2}{|c|}{$\mathrm{Ya}$} & \multicolumn{2}{|c|}{ Tidak } & & & \\
\hline & $\sum$ & $\%$ & $\sum$ & $\%$ & $\sum$ & $\%$ & \\
\hline $\begin{array}{l}\text { KPD Preterm(Usia Kehamilan } \\
\quad<37 \text { minggu }\end{array}$ & 40 & $43,5 \%$ & 52 & $56,5 \%$ & 92 & 100 & 0,039 \\
\hline $\begin{array}{c}\text { KPD Aterm(Usia } \\
\text { Kehamilan } \geq \mathbf{3 7} \text { minggu }\end{array}$ & 77 & $41,6 \%$ & 108 & $58,4 \%$ & 185 & 100 & 2,079 \\
\hline Total & 117 & 42,2 & 160 & 57,8 & 277 & 100 & \\
\hline
\end{tabular}


Berdasarkan tabel 2 menunjukkan bahwa dari 92 bayi yang lahir dari ibu yang mengalami KPD Preterm terdapat sebagian dari 40 bayi $(43,3 \%)$ yang mengalami asfiksia dan sebagian dari 52 bayi (56,5\%) tidak mengalami asfiksia. Sedangkan dari 185 bayi yang lahir dari ibu yang mengalami KPD Aterm terdapat 77 orang (41,6\%) yang bayinya mengalami asfiksia dan 108 orang $(58,4 \%)$ yang Bayinya tidak mengalami asfiksia . Hasil uji statistik didapatkan $p$ value= $0,039<0,05$, artinya ada hubungan Ketuban Pecah Dini Pada Ibu Bersalin dengan Kejadian Asfiksia Pada Bayi Baru Lahir . Nilai OR (Odds Ratio) $=2,079$

\section{PEMBAHASAN}

\section{Analisis hubungan BBLR dengan Asfiksia Neonatorum di RSUD Ade Muhammad Djoen Tahun 2020}

Berdasarkan penelitian, AnalisisHubungan BBLR dengan Asfiksia neonatorum di Rumah Sakit Umum Daerah Ade Muhammad Djoen Kabupaten Sintang tahun 2021.

Berdasarkan tabel 1 dari 170responden dapat dilihat sebagian besar berat badan lahir bayi $\geq 2500$ gram dari 170 responden $(61,4 \%)$, sedangkan sebagian yang mengalami pada berat badan lahir bayi $<2500$ gram dari 107 responden ( $38,6 \%)$.Berdasarkan table 5.4 diketahui bahwa bayi yang lahir dengan berat badan kurang dari 2500 gr sebagian mengalami asfiksia neonatorum yaitu sebesar $20,2 \%$. Sedangkan bayi yang lahir dengan berat badan lebih dari 2500 yang mengalami asfiksia neonatorum yaitu 23,8\%. Hasil pengujian menggunakanChi square memberikan hasil pvalue $=0,17>0,05$. Ha ditolak dan Ho diterima yang artinya tidak ada hubungan antara BBLR dengan asfiksia neonatorum.

Hasil penelitian ini mendukung teori dari Proverawati dan Ismawati (2010) yaitu pada berat badan lahir rendah dapat mengalami risiko jangka pendek, diantaranya adalah asfiksia. Bayi dengan berat badan lahir rendah baik yang kurang, cukup atau lebih bulan dapat mengalami gangguan pada proses adaptasi pernafasan waktu lahir sehingga dapat mengalami asfiksia neonatorum.

Bayi berat lahir rendah (BBLR) ialah bayi baru lahir yang berat badannya saat lahir kurang dari 2500 gram (sampai dengan 2499 gram). Beberapa penyakit yang berhubungan dengan prematuritas : sindrom gangguan pernafasan idiopatik (penyakit membrane hialin), pneumonia aspirasi karena reflex menelan dan batuk belum sempurna, perdarahan spontan dalam ventrikel otak lateral, akibat anoksia otak (erat kaitannya dengan gangguan pernafasan), ikterus karena fungsi hati belum matang dan hipotermia (Wiknjosastro, 2014).

Hasil penelitian sesuai dengan hasil penelitian sebelumnya di karnakan Asfiksia Neonatorum merupakan sesuatukeadaan pada bayi baru lahir yang mengalami gagal bernapas secara sepontan dan teratur segera memasukan oksigen dan tidak dapat mengeluarkan zat asam arang dari tubuhnya (Dewi, 2011). Hal ini sejalan dengan teori, BBLR terjadi pada bayi asfiksia karna fungsi hiper belum matang atau terdapat gangguan pernapasan seperti hipoksia.

Asfiksia adalah keadaan dimana bayi baru lahir tidak dapat bernapas secara spontan dan teratur. Bayi dengan riwayat gawat janin sebelum lahir, umumnya akan mengalami asfiksia pada saat dilahirkan. Masalah ini erat hubungannya dengan gangguan kesehatan ibu hamil, kelainan tali pusat, atau masalah yang mempengaruhi kesejahteraan bayi selama atau sesudah persalinan (Asuhan Persalinan Normal, 2014).

Menurut asumsi peneliti banyaknya kejadian asfiksia neonatorum yang disebabkan oleh BBLR. BBLR erat kaitannya dengan kelahiran bayi premature, sehingga terjadinya asfiksia neonatorumpada BBLR.

Peran bidan dalam mengurangi angka kejadian asfisia dan BBLR adalah memberikan penyuluhan kepada ibu hamil pada masa kehamilan, terkait penyuluha tentang asfiksia dan BBLR sehingga ibu mengerti da 
megetahui tentang asfiksia dan BBLR, ibu diharapan pada saat melahirkan dalam keadaan sehat dan bayi yang dilahirkan dalam keadaan sehat dan selamat.

\section{Analisishubungan KPD dengan Asfiksia neonatorum di RSUD Ade Muhammad Djoen Tahun 2021}

Hasil analisis bivariat dari 92 bayi yang lahir dari ibu yang mengalami KPD Preterm terdapat 40 bayi $(43,3 \%)$ yang mengalami asfiksai dan 52 bayi $(56,5 \%)$ tidak mengalami asfiksia. Sedangkan dari 185 bayi yang lahir dari ibu yang mengalami KPD Aterm terdapat 77 orang $(41,6 \%)$ yang bayinya mengalami asfiksia dan 108 orang ( 58,4\%) yang Bayinya tidak mengalami asfiksia. Hasil uji statistik didapatkan $p$ value $=0,039<0,05$, artinya ada hubungan Ketuban Pecah Dini Pada Ibu Bersalin dengan Kejadian Asfiksia Pada Bayi Baru Lahir . Nilai OR (Odds Ratio) $=2,079$

Sedangkan penelitian yang dilakukan oleh Titin Agustini tentang hubungan Ketuban Pecah Dini dengan Kejadian Asfiksia Pada Bayi Baru Lahir di Rumah Sakit Umum Daerah Kota Kendari Tahun 2017 menyatakan bahwa Ibu bersalin yang mengalami ketuban pecah dini sebagian besar bayi yang di lahirkan mengalami asfiksia, yaitu 185 orang $(39,4 \%)$ ibu bersalin yang mengalami KPD terjadi 110 bayi $(23,4 \%)$ yang mengalami asfiksia saat lahir dan 285 orang $(60,6 \%)$ ibu bersalin yang tidak mengalami KPD terdapat 160 bayi $(34,0 \%)$ tidak mengalami asfiksia saat lahir. Pengujian hipotesis memberikan hasil $p$ value $=0.001(p<0,05)$ dan nilai OR (Odds Ratio) $=1,877$.

Hasil penelitian ini menunjukkan bahwa ada hubungan ketuban pecah dini pada ibu bersalin dengan kejadian asfiksia pada bayi baru lahir di RSUD Ade Muhammad Djoen Sintang Tahun 2021 dengan $p$ value $=0.019(p<0,05)$, hal ini sesuai dan sejalan dengan penelitian yang dilakukan oleh Titin Agustini tahun 2017 yang menyatakan ada hubungan ketuban pecah dini dengan kejadian asfiksia pada bayi baru lahir di Rumah Sakit Umum Daerah Kota Kendari Tahun 2017 dengan $p$ value $=0,001(p<0,05)$ dan nilai OR(Odds Ratio $)=1,877$.
Hasil penelitian ini berbeda dengan penelitian sebelumnya yang dilakukaan oleh Titin Agustini Hubungan Ketuban Pecah Dini Dengan Kejadian Asfiksia Pada Bayi Baru Lahir di Rumah Sakit Umum Daerah Kota Kendari Tahun 2017. Jenis Penelitian ini adalah penelitian kuantitatif menggunakan metode korelasional dengan pendekatan studi retrospektif. Sedangkan penelitian sebelumnya menggunakan Deskriptif analitik dengan rancangan case control studi.

Ketuban (cairan ketuban) adalah cairan yang bening agak kekuning-kuningan ,yang mengelilingi bayi yang belum lahir (janin), bila cairan ini sudah tidak bening bahkan kehijauhijauan memperlihatkan tanda sudah terinfeksi kuman dari luar, infeksi ini mengancam janin atau tergolong dengangawat darurat janin sehingga janin perlu di selamatkan agar tidak menderita infeksi dalam kandungan ibunya (Koes Irianto,2014).

Ketuban Pecah Dini (KPD) atau ketuban pecah sebelum waktunya (KPSW) sering di sebut dengan premature rupture ofthe membrane (PROM) di definisikan sebagai pecahnya selaput ketuban sebelum waktunya melahirkan .Pecahnya ketuban sebelum persalinan atau pembukaan pada primipara kurang dari $3 \mathrm{~cm}$ dan pada multipara kurang dari $5 \mathrm{~cm}$.Hal ini dapat terjadi pada kehamilan aterm maupun pada kehamilan preterm .Pada keadaan ini dimana resiko infeksi ibu dan anak meningkat .Ketuban pecah dini merupakan masalah penting dalam masalah obstetri yang juga dapat menyebabkan infeksi pada ibu dan bayi serta dapat meningkatkan kesakitan dan kematian pada ibu dan bayi (Purwaningtyas,2017).

\section{KESIMPULAN}

Diketahui bahwa bayi yang lahir dengan berat badan kurang dari 2500 gr sebagian mengalami asfiksia neonatorum yaitu sebesar $20,2 \%$. Sedangkan bayi yang lahir dengan berat badan lebih dari 2500 yang mengalami asfiksia neonatorum yaitu 23,8\%. Hasil pengujian menggunakanChi square memberikan hasil pvalue $=0,17>0,05$. Ha ditolak dan Ho diterima yang artinya tidak ada hubungan antara BBLR dengan asfiksia neonatorum. 


\section{Diketahui dari 92 bayi yang lahir dari} ibu yang mengalami KPD Preterm terdapat sebagian dari 40 bayi $(43,3 \%)$ yang mengalami asfiksia dan sebagian dari 52 bayi $(56,5 \%)$ tidak mengalami asfiksia. Sedangkan dari 185 bayi yang lahir dari ibu yang mengalami KPD Aterm terdapat 77 orang $(41,6 \%)$ yang bayinya mengalami asfiksia dan 108 orang ( 58,4\%) yang Bayinya tidak mengalami asfiksia . Hasil uji statistik didapatkan $p$ value $=0,039<0,05$, artinya ada hubungan Ketuban Pecah Dini Pada Ibu Bersalin dengan Kejadian Asfiksia Pada Bayi Baru Lahir . Nilai OR (Odds Ratio) $=2,079$.

\section{DAFTAR PUSTAKA}

Anik Maryunani .2013. Asuhan Kegawatdaruratan Maternal \& Neonatal. Jakarta: Trans Info Medika

Anik Maryunani, Eka Puspita. 2013 .Asuhan Kegawatdaruratan Maternal \& Neonatal .Jakarta : Penerbit Trans Info Media (TIM)

Alfianika, N. 2016. Metode Penelitian Pengajaran Bahasa Indonesia. Yogyakarta : Deepublish

Depkes. 2014. Profil Kesehatan Indonesia 2014. Kesehatan Republik Indonesia

Data Rekam Medik RSUD Ade Mohammad Djoen Sintang Tahun 2020

Fadlun dan Feryanto . 2011. Asuhan Kebidanan Patologis .Jakarta : Salemba Medika.

Heriana, C. 2015. Manajemen Pengolahan Data Kesehatan. Bandung : PT Refika Aditama

Istijanto. 2014. Aplikasi Praktis Riset Pemasaran. Jakarta. PT Gramedia Utama

Jumiarni, I. 2011.Penatalaksanaan Bayi Baru Lahir. Jakarta: EGC
Kasim. 2010. Buku Ajar Neonatologi. Edisi 1.Jakarta: IDAI

Kemenkes RI. 2011. Buku saku pelayanan kesehatan neonatal esensial. Jakarta: Depkes RI.

Krisnadi, SR. 2009. Prematuritas. Bandung : PT Refika Aditama

Marmi, kukuh,Raharjo, 2014. Asuhan Neonatus Bayi Balita dan Anak Prasekolah. Yogyakarta : Pustaka Pelajar

Maryunani, A. 2013. Asuhan Kegawatdaruratan Maternal dan Neonatal. Jakarta : CV Trans Info Media

Manuaba, IBG, dkk. 2010. Penyulit pada Neonatus. Ilmu Kebidanan, Penyakit Kandungan, dan KB. Jakarta: EGC.

Mochtar , R, 2011. Sinopsis Obstetri, eds 3, Jakarta: ECG.

Nanny ,Vivian .2010.Asuhan Neonatus Bayi dan Anak Balita .Jakarta : Salemba Medika

Profil Dinas Kesehatan Kalimantan Barat Tahun 2017

Profil Kesehatan Kabupaten Sintang , 2017

Prambudi, R. 2013. Penyakit pada Neonatus.Dalam; Neonatologi Praktis.

Anugrah Utama Raharja. Cetakan Pertama. Bandar Lampung

POGI , 2014 . Pelatihan Klinik Asuhan Persalinan Normal .Jakarta : JNPK $\mathrm{KR}$

\section{DEPKES RI}

Rudi, A. 2015. Buku Ajar Analisis Data Penelitian Dengan SPSS. CV Wiyata Bhakti

Syaifudin Abdul Bari, 2014. Pelayanan Kesehatan Maternal DanNeonatal. Seto: Yogyakarta 